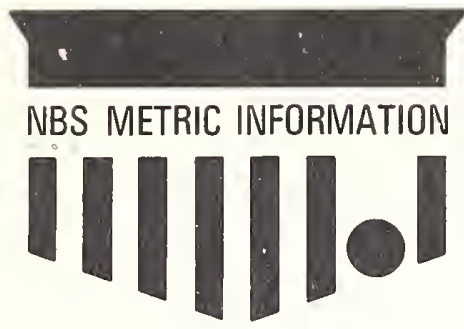

\title{
LC 1132
}

(Supersedes LC1078)

THE METRIC

SYSTEM OF

MEASUREMENTS (SI)

\section{Federal Register Notice of February 26, 1982}

April 19,1982

This NBS Letter Circular reproduces the Federal Register notice that interprets and modifies the International System of Units (SI), the Modernized Metric System, for the United States. This notice supersedes a similar notice dated October 26, 1977.

Also included is a chart that shows the relationships of all the $\mathrm{SI}$ units to which names have been assigned.

\section{May be reproduced freely}




\section{RELATIONSHIPS OF SI UNITS WITH NAMES}

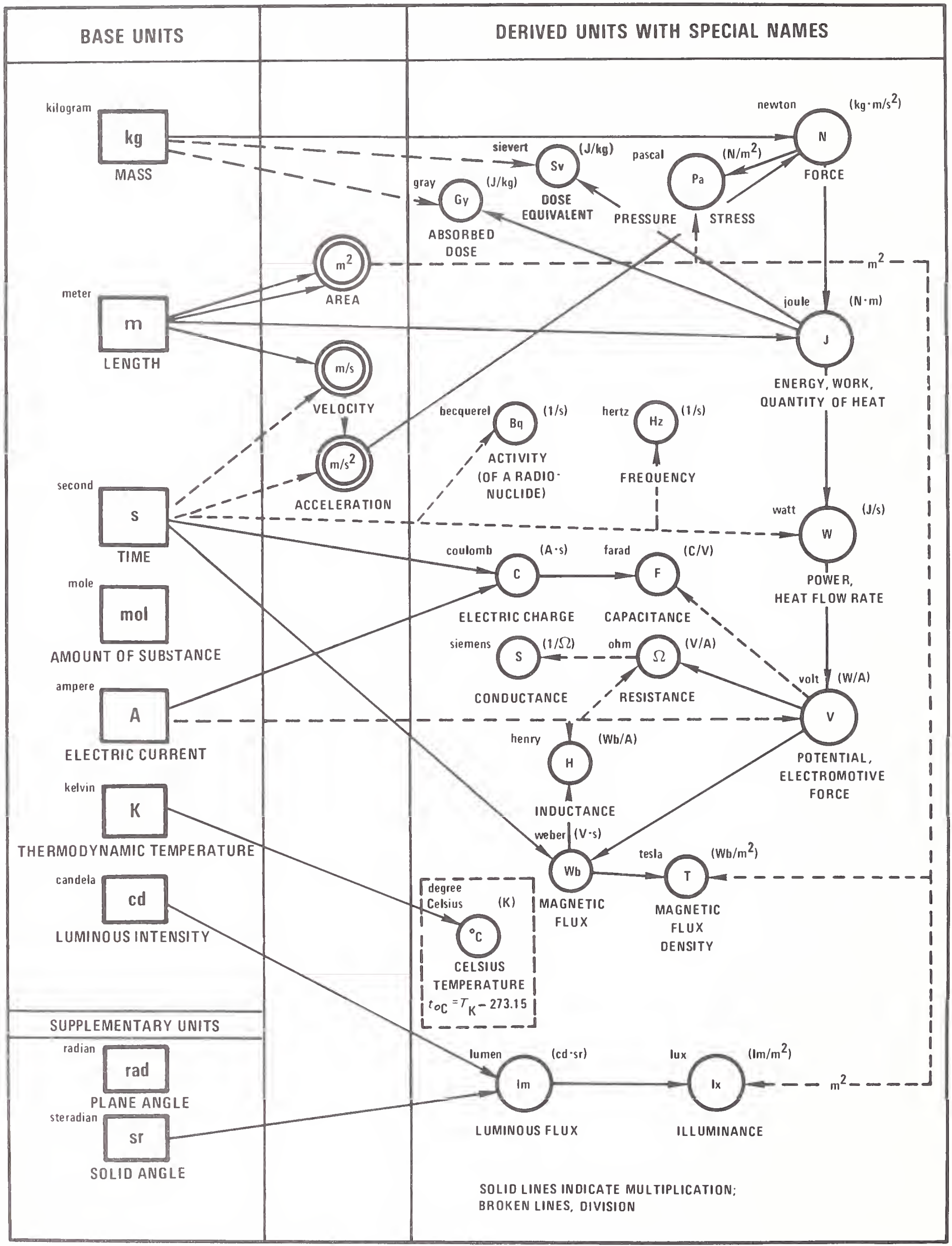


This chart shows graphically how the 19 SI derived units with special names listed in Table 2 of the Federal Register Notice, reprinted below, are derived in a coherent manner from the base and supplementary units. In the first column the symbols of the base and supplementary units are shown in rectangles, with the name of the unit shown toward the upper left of the rectangle and the name of the quantity (measurable attribute) shown below the rectangle. In the third column the symbols of the derived units with special names are shown in solid circles, with the name of the unit shown toward the upper left of the circle, the name of the quantity shown below the circle, and an expression of the derived unit in terms of other units shown toward the upper right. In the second column are shown those derived units without special names that are used in the derivation of the derived units with special names. In the chart the derivation of each unit is indicated by arrows bringing in numerator factors (solid lines) and denominator factors (broken lines)

The degree Celsius, shown on the chart in a brokenline rectangle, is a special name for the kelvin, for use in expressing Celsius temperatures or temperature intervals. Where it is used to express temperature intervals, it is equal to the kelvin, as shown on the chart, with the symbol $\mathrm{K}$ toward the upper right of the ${ }^{\circ} \mathrm{C}$ circle; where it is used to express Celsius temperatures, the equation below "CELSIUS TEMPERATURE" relates Celsius temperature $\left(t_{\mathrm{o}} \mathrm{C}\right)$ to thermodynamic temperature $\left(T_{\mathrm{K}}\right)$

\section{National Bureau of Standards}

\section{Metric System of Measurement; Interpretation and Modification of the International System of Units for the United States}

Section 3 of Pub. L. 94-168, the Metric Conversion Act of 1975, declares that the policy of the United States shall be to coordinate and plan the increasing use of the metric system in the United States. Section 403 of Pub. L. 93-380, the Education Amendments of 1974, states the policy of the United States to encourage educational agencies and institutions to prepare students to use the metric system of measurement as part of the regular education program. Under both these acts, the "metric system of measurement" is defined as the International System of Units as established by the General Conference on Weights and Measures in 1960 and interpreted or modified for the United States by the Secretary of Commerce (sec. 4(4), Pub. L. 94-168; sec. 403(a)(3). Pub. L. 93-380). The Secretary has delegated his authority under these subsections to the Director of the National Bureau of Standards.

In implementation of this authority, tables and associated materials were published in the Federal Register of October 26, 1977 (42 FR 56513-56514), setting forth the interpretation and modification of the International System of Units (hereinafter "SI") for the United States.

In accordance with recent decisions of the International Committee for Weights and Measures of the General Conference on Weights and Measures, and to refine the earlier interpretation and modification, it is deemed appropriate to amend that interpretation and modification, as published in the above-cited Federal Register notice of October 26, 1977. To assist interested parties and encourage the proper use of SI, the entire interpretation and modification, as hereby amended, is republished. Accordingly, this notice supersedes the notice of October 26, 1977.

The amendments consist of the inclusion in table 2 of the sievert, a special name for the SI derived unit of dose equivalent, the inclusion in table 6 of the electronvolt and the unified atomic mass unit, and the inclusion in table 7 of the rem, 8 unit of dose equivalent. The unit "standard atmosphere" is no longer included in table 7. The amendments are indicated by a dagger symbol ( $t)$.

The SI is constructed from seven base units for independent quantities plus two supplementary units for plane angle and solid angle, listed in table 1. 
TABLE 1.SI BASE AND SUPPLEMENTARY UNITS

\begin{tabular}{|c|c|c|}
\hline Ouantity & Name & Symbol \\
\hline SI base units. & \multirow{10}{*}{ 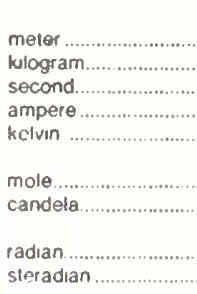 } & \multirow{10}{*}{$\begin{array}{l}\mathrm{m} \\
\mathrm{kg} \\
\mathrm{s} \\
\mathrm{A} \\
\mathrm{K} \\
\mathrm{mol} \\
\mathrm{mod} \\
\mathrm{rad} \\
\mathrm{sf}\end{array}$} \\
\hline length ....... & & \\
\hline mass '.. & & \\
\hline tıme . . ......... & & \\
\hline electric current & & \\
\hline $\begin{array}{l}\text { thermodynamic tempera- } \\
\text { ture. }\end{array}$ & & \\
\hline 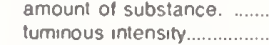 & & \\
\hline SI supplementary units. & & \\
\hline plane angle ................ & & \\
\hline solid angle ............. & & \\
\hline
\end{tabular}

"Weight" in common parlance is otten used to mean

Units for all other quantities are

derived from these nine units. In table 2 are listed $19 \mathrm{SI}$ derived units with special names which were derived from the base and supplementary units in a coherent manner, which means, in brief, that they are expressed as products and quotients of the nine base and supplementary units without numerical factors.

TABLE 2. - SI DERIVED UNITS WITH SPECIAL NAMES

\begin{tabular}{|c|c|c|c|}
\hline \multirow[b]{2}{*}{ Quantity } & \multicolumn{3}{|c|}{ SI unit } \\
\hline & Name & Symbot & $\begin{array}{l}\text { Expression } \\
\text { in terms of } \\
\text { other units }\end{array}$ \\
\hline trequency ...... & nertz. & $\mathrm{Hz}$. & $s^{-1}$ \\
\hline torce $\quad \ldots \ldots \ldots \ldots$ & newton....... & N... & $\mathrm{kg} \cdot \mathrm{m} / \mathrm{s}^{2}$ \\
\hline pressure stress.... & pascal ....... & $\mathrm{Pa} \ldots$ & $\mathrm{N} / \mathrm{m}^{2}$ \\
\hline $\begin{array}{l}\text { energy. work, } \\
\text { quantity of heat }\end{array}$ & poule ....... & J $\ldots .$. & $\mathrm{N} \cdot \mathrm{m}$ \\
\hline power, radiant llux. & walt ....... & $W \ldots$ & $\mathrm{J} / \mathrm{s}$ \\
\hline $\begin{array}{l}\text { electric charge. } \\
\text { quantity of } \\
\text { electricity }\end{array}$ & coulomb & C.... & As \\
\hline $\begin{array}{l}\text { electric potential. } \\
\text { polential } \\
\text { difterence. } \\
\text { electromotive } \\
\text { torce. }\end{array}$ & volt. & V. & W/A \\
\hline capacitance $\quad \ldots \ldots$ & tarad .... & $F \ldots$ & $\mathrm{C} / \mathrm{V}$ \\
\hline $\begin{array}{l}\text { electric resistance .... } \\
\text { conductance }\end{array}$ & $\begin{array}{l}\text { ohm ............ } \\
\text { siemens }\end{array}$ & $\begin{array}{l}\Omega \ldots \ldots \\
\mathrm{S}\end{array}$ & V/A \\
\hline magnetic itux .... & weber.. & wb... & V.s \\
\hline magnetic thux density. & tesla. .. & $\mathbf{T} \ldots \ldots$ & $\mathrm{Wb} / \mathrm{m}^{2}$ \\
\hline inductance & henry........ & H... & WD/A \\
\hline luminous flux ........... & lumen. & im... & $\mathrm{cd} \cdot \mathrm{sr}$ \\
\hline Illumnance $\ldots \ldots \ldots$ & Lux $\ldots \ldots . . . . .$. & bx $\ldots \ldots$ & $1 \mathrm{~m} / \mathrm{m}^{2}$ \\
\hline Coisus temperature'. & $\begin{array}{l}\text { degree } \\
\text { Celsus. }\end{array}$ & ${ }^{\circ} \mathrm{C} \ldots \ldots$ & k \\
\hline $\begin{array}{l}\text { activity (of a } \\
\text { rachonuctide). }\end{array}$ & becquerel. & $\mathrm{Bq}$ & $s^{-1}$ \\
\hline $\begin{array}{l}\text { absorbed dose. } \\
\text { specific energy } \\
\text { imparted, kerma. } \\
\text { absorbed dose } \\
\text { index. }\end{array}$ & gray ............... & Gy ............. & $\mathrm{J} / \mathrm{kg}$ \\
\hline $\begin{array}{l}\text { tose equivalent, } \\
\text { dose equivalent } \\
\text { index. }\end{array}$ & severt ..... & Sv. & $\mathrm{J} / \mathrm{kg}$ \\
\hline
\end{tabular}

I In addrtion 10 the thermodynamic temperature (symbol $n$ expressed in ketwins (see table 1). use is also made o Celsus temperature (symbot $n$ delined by the equation $t=T-T_{0}$ Sius" is equal to the unit "ketvin." but "degree Celsius" is a lemperature in phace of kelvin" hor expressing Colsius ditterence can be expressed in degrees Celsus as well as in

All other SI derived units, such as those in tables 3 and 4 , are similarly derived in a coherent manner from the 28 base, supplementary, and specialname SI units.
TABLE 3.-EXAMPLES OF SI DERIVED Units EXPRESSED IN TERMS OF BASE UNITS

\begin{tabular}{|c|c|c|}
\hline Quantity & St unit & $\begin{array}{l}\text { Unit } \\
\text { symbot }\end{array}$ \\
\hline area..... & square meter.. & $m^{2}$ \\
\hline volume .......... & cubic meter ........... & $m^{3}$ \\
\hline speed. velocity... & meter per second & $\mathrm{m} / \mathrm{s}$ \\
\hline acceleration .............. & $\begin{array}{l}\text { meler per second } \\
\text { squared. }\end{array}$ & $\mathrm{m} / \mathrm{s}^{2}$ \\
\hline wave number ...... & 1 per meter ....... & $\mathrm{nn}^{-1}$ \\
\hline density, mass density & $\begin{array}{l}\text { kilogram per cubic } \\
\text { meter. }\end{array}$ & $\mathrm{kg} / \mathrm{m}^{3}$ \\
\hline specitic volume... & $\begin{array}{l}\text { cubic meter per } \\
\text { kulogram. }\end{array}$ & $m^{3 / k g}$ \\
\hline current density. & $\begin{array}{l}\text { ampere per square } \\
\text { meter. }\end{array}$ & $\mathrm{A} / \mathrm{m}^{2}$ \\
\hline $\begin{array}{l}\text { magnetic field strength } \\
\text { concentration (ot } \\
\text { amount of substance) }\end{array}$ & $\begin{array}{l}\text { ampere per meter. } \\
\text { mole per cubic meter }\end{array}$ & $\begin{array}{l}\mathrm{A} / \mathrm{m} \\
\mathrm{mol} / \mathrm{m}^{\prime \prime}\end{array}$ \\
\hline luminance ..... . & $\begin{array}{l}\text { candela per square } \\
\text { meter. }\end{array}$ & $\mathrm{cd} / \mathrm{m}^{2}$ \\
\hline
\end{tabular}

TABLE 4.-EXAMPLES OF SI DERIVED UNITS EXPRESSED BY MEANS OF SPECIAL NAMES

\begin{tabular}{|c|c|c|}
\hline Quanlity & Name & Unt symbol \\
\hline oynamic viscosity. & pascal second.... & Pa.s \\
\hline moment of torce & newton meter ...... & $\mathrm{Nm}$ \\
\hline surface lension.. & newton per meter & $\mathrm{N} / \mathrm{m}$ \\
\hline $\begin{array}{l}\text { heat flux density. } \\
\text { irradiance }\end{array}$ & $\begin{array}{l}\text { watl per square } \\
\text { meter }\end{array}$ & $W / m^{2}$ \\
\hline $\begin{array}{l}\text { heat capacity. } \\
\text { entropy }\end{array}$ & fowle per ketvin & $J / K$ \\
\hline $\begin{array}{l}\text { specilic heat } \\
\text { capacity, specric } \\
\text { entropy }\end{array}$ & $\begin{array}{l}\text { poule per kilogram } \\
\text { kelvm. }\end{array}$ & $J /(k g K)$ \\
\hline specilic energy ....... & foule per kilogram & $\mathrm{J} / \mathrm{kg}$ \\
\hline thermal conchuctivity. & watt per meler kelvin & $W /(m \cdot k)$ \\
\hline $\begin{array}{l}\text { energy density } \\
\text { electric theld strength. }\end{array}$ & $\begin{array}{l}\text { joule per cubic meter } \\
\text { volt per meter }\end{array}$ & $\begin{array}{l}\mathrm{J} / \mathrm{m}^{3} \\
\mathrm{~V} / \mathrm{m}\end{array}$ \\
\hline $\begin{array}{l}\text { electric charge } \\
\text { density }\end{array}$ & $\begin{array}{l}\text { coutomb per cubic } \\
\text { meter. }\end{array}$ & $\mathrm{c} / \mathrm{m}^{3}$ \\
\hline evectric thax density & $\begin{array}{l}\text { coutomb per square } \\
\text { meter }\end{array}$ & $\mathrm{C} / \mathrm{m}^{2}$ \\
\hline permittivity ............. & farad per meter .......... & $\mathrm{F} / \mathrm{m}$ \\
\hline permeability .............. & henry per meter ............ & $\mathrm{H} / \mathrm{m}$ \\
\hline molar energy ............... & joule per mole ........... & $\mathrm{J} / \mathrm{mol}$ \\
\hline $\begin{array}{l}\text { molar entropy, molar } \\
\text { heat capacity. }\end{array}$ & foule per mole kelurn & $\mathrm{J} /(\mathrm{mol} \cdot \mathrm{K})$ \\
\hline $\begin{array}{l}\text { exposure ( } x \text { and } \gamma \\
\text { rays). }\end{array}$ & coulomb per kilogram & $\mathrm{C} / \mathrm{kg}$ \\
\hline absorbed dose rate.. & gray per second ............ & Gy/s \\
\hline
\end{tabular}

For use with the SI units there is a set of 16 prefixes (see table 5) to form multiples and submultiples of these units. It is important to note that the kilogram is the only SI unit with a prefix. Because double prefixes are not to be used, the prefixes of table 5 , in the case of mass, are to be used with gram (symbol g) and not with kilogram (symbol kg).

TABLE 5.-SI PREFIXES

\begin{tabular}{|c|c|c|}
\hline Faclor & Prefix & Symbol \\
\hline $10^{18}$ & exa. & $E$ \\
\hline $10^{15}$. & peta ................... & $\mathbf{P}$ \\
\hline $10^{12} \ldots \ldots \ldots \ldots \ldots \ldots$ & 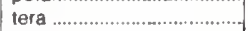 & $\mathrm{T}$ \\
\hline $10^{9} \ldots$ & grga $\ldots \ldots \ldots . . . . . .$. & G \\
\hline $10^{8} \ldots \ldots \ldots \ldots \ldots \ldots$ & mega & $M$ \\
\hline $10^{3} \ldots \ldots \ldots \ldots \ldots \ldots$ & 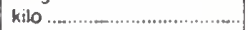 & k \\
\hline $10^{2}$. & hecto & $\mathrm{n}$ \\
\hline $10^{\prime} \ldots$. & 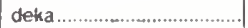 & da \\
\hline $10^{-1}$ & 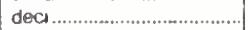 & d \\
\hline $10^{-2} \ldots$ & centi............................... & c \\
\hline $10^{-} \cdot$. & 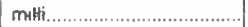 & $\mathbf{m}$ \\
\hline $10^{-6}$ & mucro & $\mu$ \\
\hline $10^{-9}$. & nano. & n \\
\hline $10^{-12}$ & pro & p \\
\hline $10^{-19} \ldots \ldots \ldots \ldots$ & temto ................................. & $i$ \\
\hline $10^{-18} \ldots \ldots \ldots \ldots$ & 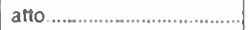 & a \\
\hline
\end{tabular}

Certain units that are not part of the SI are used so widely that it is impractical to abandon them. The units that are accepted for continued use in the United States with the International System are listed in table 6.

TABLE 6.- UNITS IN USE WITH THE INTERNATIONAL SYSTEM

\begin{tabular}{|c|c|c|}
\hline Name & Symbot & Value in $\mathrm{S} 1$ unit \\
\hline minule (tıme)... & $\min$. & $1 \mathrm{~min}=60 \mathrm{~s}$ \\
\hline hout .................... & & $1 \mathrm{~h}=60 \mathrm{~min}=3600 \mathrm{~s}$ \\
\hline day ......... & & $1 \mathrm{~d} 24 \mathrm{~h} 86400 \mathrm{~s}$ \\
\hline degree (angle) & & $1^{\circ}-(\pi / t 80) \mathrm{rad}$ \\
\hline minute (angle) .. & & $1=(1 / 60)^{\circ}$ \\
\hline second '(angle). & & $\begin{aligned} & =(\mathrm{a} / 10 \mathrm{B00}) \mathrm{rad} \\
1^{\prime \prime} & =(1 / 60)^{\prime}\end{aligned}$ \\
\hline & & $\begin{array}{c}=(\pi / 648000) \mathrm{rad} \\
1 \mathrm{~L}=1 \mathrm{dm}^{3}=10^{-3} \mathrm{~m}^{3}\end{array}$ \\
\hline metric ion ....... & & $1 \mathrm{t}=10^{3} \mathrm{~kg}$ \\
\hline hectare (tand area) & & 1 ha $=10^{4} \mathrm{~m}^{2}$ \\
\hline telectronvolt......... & & $\begin{array}{l}1 \mathrm{eV}=1.602 \times 10^{-10} \mathrm{~J} \text {, ap- } \\
\text { proxamately }\end{array}$ \\
\hline $\begin{array}{l}\text { tunnilied atomic } \\
\text { mass unrt. }\end{array}$ & U ............. & $\begin{array}{l}1 \mathrm{u}=1.66057 \times 10^{-27} \mathrm{~kg}, \\
\text { approximately }\end{array}$ \\
\hline
\end{tabular}

3oth $L$ and I are international symbols for liter Because "can eastly be contused with the numeral " 1 " the symbot ". Is recommended tor United States use.

- The values of these units in terms of SI units are obtaned experimentally.

In those cases where their usage is already well established, the use, for a limited time, of the units in table 7 is accepted, subject to future review.

\section{TABLE 7.-UNITS IN USE TEMPORARILY WITH THE INTERNATIONAL SYSTEM}

\begin{tabular}{lll}
$\begin{array}{l}\text { nautical mile } \\
\text { knot }\end{array}$ & $\begin{array}{l}\text { angstrom } \\
\text { barn } \\
\text { bat } \\
\text { gal " }\end{array}$ & $\begin{array}{l}\text { curne } \\
\text { roentgen } \\
\text { rad }^{2} \\
\text { trem }\end{array}$ \\
\hline $\begin{array}{l}\text { I Unit of acceteration. } \\
2 \text { Unit of absorbed dose. } \\
\text { 3 Unit of dose equivalent. }\end{array}$ &
\end{tabular}

Metric units, symbols, and terms that аге not in accordance with the foregoing Interpretation and Modification are no longer accepted for continued use in the United States with the International System of Units. Accordingly, the following units and terms listed in the table of metric units in section 2 of the Act of July 28, 1866 that legalized the metric system of weights and measures in the United States are no longer accepted for use in the United States: myriameter

stere

millier or tonneau

quintal

myriagram

kilo (for kilogram)

For more information regarding the International System of Units, contact Dr. David T. Goldman, National Measurement Laboratory, National Bureau of Standards, U.S. Department of Commerce, Washington, D.C. 20234. telephone (301) 921-3304.

Dated: February 2, 1982.

Emest Ambler,

Director.

[FR Doc. 82-5150 Filed 2-25-82; 8:45 am]

BILLING COOE 3510-12- 